It is hoped that the study of the three rock-suites, plus consideration of the data available for the other Gardar intrusives, will allow some comment to be made on the relationships between aegirine, riebeckite, astrophyllite and aenigmatite, the four principal "peralkaline" ferromagnesian minerals.

The study is being carried out at the University of Edinburgh as part of a Ph. D. studentship, under the supervision of Dr. B. G. J. Upton.

References

Bailey, D. K. , and Schairer, J. F. (1966) The system $\mathrm{Na}_{2} \mathrm{O}-\mathrm{Al}_{2} \mathrm{O}_{3}-\mathrm{Fe}_{2} \mathrm{O}_{3}-\mathrm{SiO}_{2}$ at 1 atmosphere and the petrogenesis of alkaline rocks. J. Petrol., Vol. 7, 114-170.

Upton, B. G. J. (1964) The geology of Tugtutôq and neighbouring islands, South Greenland. Part II. Nordmarkitic syenites and related alkaline rocks. Medd. Grфnland, Bd.169, Nr.2.

\title{
REPORT ON THE SURVEY OF BERYLLIUM, NIOBIUM, URANIUM AND THORIUM MINERALIZATION IN THE ILÍMAUSSAQ COMPLEX, SOUTH GREENLAND
}

\section{John Hansen}

A survey of uranium, thorium and niobium mineralization in the Ilímaussaq alkaline intrusion which was started in 1964 was extended in 1965 to include a survey of beryllium mineralization. This was continued during 1966 .

The Ilímaussaq complex is an intrusion dominantly built up of an early augite syenite followed by nepheline syenites (an agpaitic suite consisting. mainly of naujaites, kakortokites and lujavrites).

The beryllium minerals are generally found in late hydrothermal veins consisting of albite, analcime, natrolite and ussingite, but are also found disseminated in the naujaite especially where it is albitized. These veins are from less than one millimetre to $2 \mathrm{~cm}$ wide. Most of the veins are found in 
the naujaites, but some are found in the coarse-grained lujavrites on the Kvanefjeld plateau. The most important of the beryllium minerals is chkalovite, but several other beryllium minerals have been found (Table 1).

Table 1

Beryllium minerals found in the Ilímaussaq intrusion

\begin{tabular}{l|l|c}
\hline Mineral & Formula & $\% \mathrm{BeO}$ \\
\hline Bertrandite & $\mathrm{Be}_{4}\left(\mathrm{Si}_{2} \mathrm{O}_{7}\right)(\mathrm{OH})_{2}$ & $40-43$ \\
Beryllite & $\mathrm{Be}_{3} \mathrm{SiO}_{4}(\mathrm{OH})_{2} \mathrm{H}_{2} \mathrm{O}$ & 40 \\
Chkalovite & $\mathrm{Na}_{2} \mathrm{BeSi}_{2} \mathrm{O}_{6}$ & $11-13$ \\
Epididymite & $\mathrm{Na}\left(\mathrm{BeSi}_{3} \mathrm{O}_{7}\right)(\mathrm{OH})$ & 11 \\
Eudidymite & $\mathrm{Na}\left(\mathrm{BeSi}_{3} \mathrm{O}_{7}\right)(\mathrm{OH})$ & 11 \\
Genthelvite & $\mathrm{Zn}_{8}\left(\mathrm{BeSiO}_{4}\right)_{6} \mathrm{~S}_{2}$ & $11-14$ \\
Leucophane & $\mathrm{NaCa}\left(\mathrm{BeSi}_{2} \mathrm{O}_{6}\right) \mathrm{F}$ & $10-12$ \\
Sorensenite & $\mathrm{Na}_{4} \mathrm{SnBe}_{2} \mathrm{Si}_{2} \mathrm{O}_{16}(\mathrm{OH})_{4}$ & $7-8$ \\
Spherobertrandite & $\mathrm{Be}_{5}\left(\mathrm{Si}_{2} \mathrm{O}_{7}\right)(\mathrm{OH})_{4}$ & $40-43$ \\
Tugtupite & $\mathrm{Na}_{8} \mathrm{Be}_{2} \mathrm{Al}_{2} \mathrm{Si}_{8} \mathrm{O}_{24}(\mathrm{Cl}, 2, \mathrm{~S})$ & 5 \\
\hline
\end{tabular}

In the same hydrothermal veins as the beryllium there are also niobium minerals. Niobium minerals are also disseminated in sheared lavas, anorthosite gabbro and augite syenites on the Kvanefjeld plateau. The most important of the niobium minerals are pyrochlore and minerals of the epistolite-murmanite group, but several other niobium minerals have been found in the complex (Table 2). All the niobium minerals, with the exception of murmanite, are found in the hydrothermal veins, while murmanite is the disseminated niobium mineral on Kvanefjeld. Murmanite, epistolite and pyrochlore constitute from less than $1 \%$ to more than $10 \%$ of the rock. It is suggested that the niobium is derived from the lujavrite magma and its later differentiates.

The beryllium and niobium minerals are being studied and published as a series of "Contributions to the mineralogy of Ilimaussaq" in Meddelelser om Gronland, volume 181.

The uranium-thorium survey was also continued during the summer of 1966 using a scintillation counter and a single channel analyzer to measure the $U$ and $T h$ in situ. Steenstrupine, monazite (a special uranium-rich variety) and thorite occur in the lujavrites, coarse-grained lujavrites and late hydrothermal veins. The mineralization is strongest in the contact zone between the lavas that form a roof and the underlying coarse-grained lujavrites on the Kvanefjeld plateau. Detailed work has shown that the mineralization on 
Table 2

Niobium minerals found in the Ilimaussaq intrusion

\begin{tabular}{l|l|c}
\hline Mineral & Formula & $\% \mathrm{Nb}_{2} \mathrm{O}_{5}$ \\
\hline Epistolite & $(\mathrm{Na}, \mathrm{Ca})(\mathrm{Nb}, \mathrm{Ti}, \mathrm{Mg}, \mathrm{Fe}, \mathrm{Mn})(\mathrm{OH}) \mathrm{SiO}_{4}$ & 32 \\
Gerassimovskite & $\mathrm{TiNb}(\mathrm{OH})_{9}$ & 41 \\
Igdloite & $\mathrm{NaNbO}_{3}$ & 62 \\
Ilímaussite & $\mathrm{Na}_{4} \mathrm{Ba}_{2} \mathrm{CeFeNb} \mathrm{Si}_{8} \mathrm{O}_{28} .5 \mathrm{H}_{2} \mathrm{O}$ & 13 \\
Murmanite & $\mathrm{Na}(\mathrm{Ti}, \mathrm{Nb})(\mathrm{OH}) \mathrm{SiO}_{4}$ & $0.6-9$ \\
Nenadkevichite & $(\mathrm{Ba}, \mathrm{K}, \mathrm{Na})(\mathrm{Ti}, \mathrm{Nb}) \mathrm{Si}_{2} \mathrm{O}_{7} \cdot \mathrm{H}_{2} \mathrm{O}$ & 28 \\
Niobophyllite & $(\mathrm{Na}, \mathrm{K}, \mathrm{Ca}, \mathrm{Ce})_{3}(\mathrm{Fe}, \mathrm{Mg}, \mathrm{Mn})_{6} \cdot 7$ & \\
& $(\mathrm{Ti}, \mathrm{NbTa})_{2}\left(\mathrm{~A} 1, \mathrm{Si}_{8} \mathrm{O}_{25}(\mathrm{OH}, \mathrm{F})_{6}\right.$ & 9 \\
Pyrochlore & $(\mathrm{Na}, \mathrm{Ca})_{2}(\mathrm{Nb}, \mathrm{Ta}, \mathrm{Ti})_{2} \mathrm{O}_{6}(\mathrm{OH}, \mathrm{F}, \mathrm{O})$ & $41-59$ \\
Tundrite & $\mathrm{Na}_{2}(\mathrm{Nb}, \mathrm{Ce})_{4}(\mathrm{Ti}, \mathrm{Nb})_{2} \mathrm{Si}_{2} \mathrm{O}_{15} \cdot 8 \mathrm{H}_{2} \mathrm{O}$ & 6 \\
\hline
\end{tabular}

Kvanefjeld plateau is much larger than the earlier suggestion of $10 \times 10^{6}$ tons ore with 4000 tons $U$ and 10000 tons Th.

In connection with the development of an extraction process of uranium by a flotation process a survey of the water supply in the nearby river that was started in 1965 was continued during 1966. This also forms part of the contribution to the UNESCO International Hydrological Decade Programme (this report p. 50).

A portable detector (beryllometer) constructed by the Danish Atomic Energy Commission (A. E. C.), Electronics Department, was used in the survey of the beryllium mineralization. The beryllometer is based on the photo-disintegration process in the beryllium nucleus, a well-established process in the assay of Be-bearing ores. The $\gamma$ source used is of $100 \mathrm{mCi}$ $\mathrm{Sb}^{124}$ mounted in a moveable lead shield, the neutrons released being detected by means of two $\mathrm{BF}_{3}$ counters in a paraffin wax moderator. The counting rate of the neutrons is $1.2 \mathrm{cpm} / \% \mathrm{BeO} / \mathrm{mCi} \mathrm{Sb}^{124}$, and a sensitivity of $20-30$ ppm has been estimated. The weight of the instrument is $41 \mathrm{~kg}$. New beryllometers of lighter weight are under construction, and a more sensitive version using $\mathrm{He}^{3}$-filled neutron counters is being developed. 